\title{
ЦЕРЕБРОПРОТЕКТОРНА АКТИВНІСТЬ НОВОГО ПОХІДНОГО 4-АМІНОБУТАНОВОЇ КИСЛОТИ ЗА УМОВ ЕКСПЕРИМЕНТАЛЬНОЇ ЗАКРИТОЇ ЧЕРЕПНО-МОЗКОВОЇ ТРАВМИ
}

Вступ. Для лікування когнітивних розладів у комплексній терапії черепно-мозкової травми широко використовують церебропротектори і ноотропи.

Мета дослідження - вивчити церебропротекторну активність сполуки КГМ-5, що є новим похідним 4-амінобутанової кислоти.

Методи дослідження. Закриту черепно-мозкову травму (ЗЧМТ) відтворювали ущурів масою 200-220 г під легким ефрірним наркозом за допомогою вантажу масою 0,1 ке, що вільно падає по вертикальному каналу з енергією удару 0,589 Дж на голову тварин. Усього було використано 35 білих нелінійних щурів-самців, яких поділили на групи: 1-ша - інтактний контроль; 2-га - тварини зі змодельованою 3ЧМТ; 3-тя тварини зі змодельованою ЗЧМТ, яким внутрішньошлунково вводили сполуку КГМ-5 у дозі 30 мг/ке; 4-та i 5-та - тварини, яких лікували, відповідно, препаратами порівняння гопантеновою кислотою (150 мг/кг внутрішньошлунково) та пірацетамом (300 мг/ке внутрішньошлунково) впродовж 3 діб до і 5 діб після моделювання ЗЧМТ. На 1-шу, 2-гу і 3-тю доби після відтворення ЗЧМТ визначали ступінь неврологічного дефрiциту (в балах) за шкалою McGraw, на 4-ту - фрункціональний стан ЦНС тварин у тесті "відкрите поле", на 5-ту - когнітивні фрункції в тесті екстраполяційного вивільнення.

Результати й обговорення. На тлі дії досліджуваних засобів встановлено зменшення неврологічного дефріциту порівняно з групою контрольної патології на 1-шу та 2-гу доби, проте достовірний характер ці відмінності мали лише на 1-шу добу. В тесті "відкрите поле" рухова та дослідницька активність і загальна сума всіх видів активності на фроні дії всіх засобів була достовірно вищою, ніж у групі контрольної патології. У тесті екстраполяційного вивільнення як у загальній групі тварин, так і серед щурів, які здатні виконувати тест, сполука КГМ-5 статистично значуще поліпшувала когнітивні фрункції тварин: зменшувала час виконання завдання.

Висновок. На моделі закритої черепно-мозкової травми у щурів встановлено церебропротекторну активність нового похідного 4-амінобутанової кислоти - сполуки КГМ-5 за здатністю зменшувати вираження неврологічного дефіциту впродовж перших двох діб патології, запобігати зниженню локомоторної активності тварин та покращувати когнітивні фрункції.

КЛЮЧОВІ СЛОВА: нове похідне 4-амінобутанової кислоти КГМ-5; модель закритої черепно-мозкової травми; неврологічний дефіцит; стан ЦНС; когнітивні фрункції.

ВСТУП. За даними статистики, черепно-мозкова травма є головною причиною загибелі та непрацездатності в посттравматичний період для людей, молодших 50 років, при цьому чоловіки страждають у 2,5 раза частіше, ніж жінки. Вона часто призводить до тяжкої інвалідизації і значного зниження якості життя [1]. Ступінь порушень визначається характером травматичного впливу на мозок, що може призвести до тимчасового або постійного погіршення пізнавального, фрізичного і психосоціального стану. Черепно-мозкова травма - складна травматична хвороба, яка завдає структурної шкоди і викликає фрункціональні десріцити, що відбувають(с) Н. Ю. Палагіна, 2021. ся як через основне механічне, так і в результаті безпосереднього руйнування мозкової тканини. Вона стається під час впливу зовнішньої сили та включає контузію, ушкодження кровоносних судин (крововиливи), нервових клітин і аксональних відростків нейронів. Вторинне ушкодження розвивається за хвилини і через місяці після отримання первинної травми в результаті каскадів метаболічних, клітинних та молекулярних подій, які у кінцевому рахунку призводять як до рухових, так і неврологічних та когнітивних розладів [2-5].

Для лікування когнітивних розладів у комплексній терапії черепно-мозкової травми широко використовують церебропротектори, ноотро- 
пи, які не завжди $є$ ефективними і безпечними [6]. У зв'язку 3 цим, пошук нових ноотропних препаратів, здатних поліпшувати когнітивні порушення, що виникли в результаті отримання черепно-мозкової травми, $є$ актуальним науковим завданням. Перспективними в цьому відношенні $є$ нові похідні 4-амінобутанової кислоти, синтезовані в Національному фрармацевтичному університеті, серед 11 з яких було обрано субстанцію-лідер за антиамнестичною активністю під шифром КГМ-5, що проявляє також і антигіпоксичну активність [7]. 3 огляду на вищесказане, доцільним було вивчити її здатність покращувати порушений стан головного мозку щурів за умов експериментальної черепно-мозкової травми.

Мета дослідження - на моделі закритої черепно-мозкової травми у щурів вивчити церебропротекторну активність сполуки КГМ-5 за антиамнестичною активністю.

МЕТОДИ ДОСЛІДЖЕННЯ. Закриту черепно-мозкову травму (ЗЧМТ) відтворювали у щурів масою 200-220 г під легким ефрірним наркозом за допомогою вантажу масою 0,1 кг, що вільно падає по вертикальному каналу з енергією удару 0,589 Дж [8]. Голову тварин фріксували на поролоновій підкладці, яка запобігала перелому нижньої щелепи, таким чином, щоб центр удару припадав точно по сагітальній лінії на 5 мм уперед від інтраурикулярної лінії.

Досліджувану субстанцію КГМ-5 вводили внутрішньошлунково в умовно-ефективній дозі 30 мг/кг упродовж 3 діб до та 5 діб після моделювання ЗЧМТ. Як препарати порівняння було використано аналоги за структурою (похідні ГАМК) та за дією: циклічний ГАМК пірацетам (таблетки 400 мг, “Пірацетам-Дарниця®”, виробництво “Дарниця ФФ ПрАТ”, Україна) і гопантенову кислоту (ГПК) (таблетки 500 мг, "Когнум", виробництво КВ3) у дозах, відповідно, 400 та 150 мг/кг. Дозу пірацетаму обрано на основі даних [9] щодо його ефективності в експерименті при внутрішньошлунковому введенні в дозах 200 та 400 мг/кг. Дозу гопантенової кислоти розраховано, виходячи з добової дози для людини з урахуванням коефріцієнта видової чутливості [10].

Усього було використано 35 білих нелінійних щурів-самців. Тварин рандомізували на 5 груп по 7 щурів у кожній: 1-ша - інтактний контроль; 2-га - тварини зі змодельованою ЗчМТ; 3-тя тварини зі змодельованою ЗЧМТ, яких лікували сполукою КГМ-5; 4-та і 5-та - тварини, яких лікували, відповідно, препаратами порівняння гопантеновою кислотою та пірацетамом. Кількість використаних в експерименті тварин було об- ґрунтовано на засіданні комісії з питань біоетики Національного фрармацевтичного університету (НФаУ) (протокол № 5 від 25.03.2021 р.). Дослідження проводили на базі Навчально-наукового тренінгового центру медико-біологічних досліджень Навчально-наукового інституту прикладної фрармації НФаУ навесні 2021 р. Під час експерименту тварин утримували у віварії тренінгового центру НФаУ при температурі повітря 20-22 ${ }^{\circ} \mathrm{C}$, природному світловому режимі “день ніч", у стандартних клітках, на стандартному харчовому раціоні.

Усі маніпуляції з тваринами проводили відповідно до вимог GLP, рекомендацій Державного експертного центру МОЗ України, Загальних етичних принципів експериментів на тваринах (Україна, 2001 р.), Закону України від 21 лютого 2006 р. № 3447-IV зі змінами "Про захист тварин від жорстокого поводження", ухвали I Національного конгресу з біоетики (Київ, 2007 р.), Європейської конвенції про захист хребетних тварин, що використовуються для дослідних та інших наукових цілей [11].

На 1-шу, 2-гу, 3-тю доби після відтворення зчМТ встановлювали ступінь неврологічного десріциту (в балах) за шкалою McGraw [12]. Тяжкість стану визначали за сумою балів: до 3 балів - легкий ступінь, 3-7 - середній, 7 та вище - тяжкий. щурів тестували щоденно, підраховуючи бали. Відмічали парези, паралічі кінцівок, тремор, манежні рухи, птоз, положення на боку, рухливість тварин. Функціональний стан ЦНС щурів оцінювали на 4-ту добу в загальновживаному тесті “відкрите поле” [12]. Когнітивні функції вивчали на 5-ту добу після моделювання ЗЧМТ у тесті екстраполяційного вивільнення, який дозволяє охарактеризувати здатність тварини до знаходження шляху виходу 3 гострої стресової ситуації [12]. Час проведення тесту обмежували 180 с.

Статистичну обробку проводили за допомогою програми STATISTICA 6.0 (StatSoft, Inc., США), перевіряли нормальність розподілу 3 використанням W-критерію Шапіро - Уїка. Було встановлено, що дані підлягають ненормальному розподілу, тому використовували непараметричний U-критерій Манна - Уїтні. Результати представляли як медіану (Ме) та інтерквартильний розмах (процентилі 25-75). Прийнято рівень значущості $p<0,05$ [13].

РЕЗУЛЬТАТИ Й ОБГОВОРЕННЯ. ПрОТЯГОМ усього терміну спостереження після відтворення ЗЧМТ летальності щурів не спостерігали. Це відповідало помірній тяжкості модельної патології, яку обрано з метою характеристики церебропротекторних властивостей сполуки КГМ-5. 
Таблиця 1 - Вплив субстанції КГМ-5 та препаратів порівняння на вираження неврологічного дефіциту в щурів (бали за шкалою McGraw) після моделювання закритої черепно-мозкової травми (M (Min $\div$ Max), $\mathrm{n}=7$ )

\begin{tabular}{|c|c|c|c|c|c|c|}
\hline \multirow[b]{2}{*}{$\begin{array}{c}\text { Термін } \\
\text { досліджен- } \\
\text { ня, доби }\end{array}$} & \multicolumn{5}{|c|}{ Група тварин } & \multirow{2}{*}{$\begin{array}{c}\text { Значення } \\
\text { критерію } \\
\text { Крускала - } \\
\text { Уолліса }\end{array}$} \\
\hline & $\begin{array}{l}\text { інтактний } \\
\text { контроль }\end{array}$ & $\begin{array}{c}\text { контрольна } \\
\text { патологія } \\
\text { (ЗЧМТ) }\end{array}$ & $\begin{array}{c}\text { 3чМТ+КГМ-5, } \\
30 \mathrm{Mг/кг}\end{array}$ & $\begin{array}{c}\text { ЗЧМТ+ГПК, } \\
150 \text { мг/кг }\end{array}$ & $\begin{array}{c}\text { 3чМТ+пірацетам, } \\
300 \text { мг/кг }\end{array}$ & \\
\hline 1-ша & $0(0 \div 0)$ & $0,5(0,5 \div 1)^{\star}$ & $0(0 \div 0,5)^{\star *}$ & $0(0 \div 0,5)^{\star \star}$ & $0(0 \div 0,5)^{\star \star}$ & 0,0034 \\
\hline 2-га & $0(0 \div 0)$ & $0,5(0 \div 0,5)^{\star}$ & $0(0 \div 0,5)$ & $0(0 \div 0,5)$ & $0(0 \div 0,5)$ & 0,2451 \\
\hline 3-тя & $0(0 \div 0)$ & $0(0 \div 0,5)$ & $0(0 \div 0)$ & $0(0 \div 0)$ & $0(0 \div 0)$ & 0,0831 \\
\hline
\end{tabular}

Примітки. Тут і в таблиці 2:

1. Використано критерій Манна - Уїтні.

2. * - рівень статистичної значущості при порівнянні з інтактним контролем $(p<0,05)$.

3. ** - рівень статистичної значущості при порівнянні з групою контрольної патології $(p<0,05)$.

4. n - кількість тварин у групі.

Як видно з даних, наведених у таблиці 1, вираження неврологічного дефіциту в тварин було незначним, статистично значущі відмінності між групами спостерігали тільки на 1-шу добу. Під впливом усіх трьох досліджуваних засобів на 1-шу та 2-гу доби зменшувався неврологічний десріцит порівняно з групою контрольної патології, проте достовірний характер ці відмінності мали лише на 1-шу добу. Досліджувана сполука КГМ-5 за ефрективністю впливу на неврологічний десіцит відповідала дії препаратів порівняння гопантенової кислоти і пірацетаму.

Результати дослідження впливу сполуки КГМ-5 на поведінкові реакції тварин з моделлю ЗЧМТ у тесті “відкрите поле” наведено в таблиці 2.

У тварин групи контрольної патології спостерігали посилення порушень поведінкових реакцій, що проявилось достовірним зниженням кількості перетинань квадратів (3 16,75 до 1,17, p<0,05), вертикальних стійок (3 2,00 до 0,17, p<0,05) та досліджуваних отворів (3 6,25 до 2,67, p<0,05) i, як наслідок, суми всіх видів активності (в 6,5 раза).
Профрілактичне введення досліджуваних засобів значною мірою пом'якшувало порушення орієнтовно-рухової активності у щурів після моделювання ЗЧМТ. Рухова та дослідницька активність на тлі дії засобів хоча і не досягала рівня інтактного контролю, але була достовірно більшою, ніж у групі контрольної патології. Загальна сума всіх видів активності в дослідних групах також була достовірно вищою за значення в групі контрольної патології.

Таким чином, отримані дані свідчать про церебропротекторну активність сполуки КГМ-5, еорективність якої була на рівні препаратів порівняння - пірацетаму і гопантенової кислоти.

Результати, отримані в тесті “відкрите поле”, цілком відображають їх фрармакологічні властивості. Пірацетам $€$ ноотропним засобом зі стимулювальними властивостями [14], гопантенова кислота, залежно від дози, має модулювальний вплив на стан ЦНС [15], сполука КГМ-5 проявляє седативні властивості [7].

Отже, сполука КГМ-5 має переваги, порівняно з гопантеновою кислотою, у віддалені термі-

Таблиця 2 - Вплив сполуки КгМ-5 та препаратів порівняння на поведінкові реакції в щурів у тесті "відкрите поле" на 4-ту добу після моделювання закритої черепно-мозкової травми (M (Min-Max), n=7) 
ни після моделювання ЗЧМТ у щурів, зумовлюючи менше зниження локомоторної активності без подальших зсувів орієнтовно-дослідницької активності та недостовірне зростання вираження емоційного і вегетативного супроводу поведінкових реакцій.

У тесті екстраполяційного вивільнення, що характеризує когнітивні фрункції, встановлено подовження часу пірнання як у загальній групі тварин з контрольною патологією, так і в щурів, які виконали тест. Проте ці відмінності були недостовірними порівняно з інтактним контролем (табл. 3).

Препарати порівняння (гопантенова кислота і пірацетам) сприяли зменшенню часу пірнання як серед усіх тварин, так і серед щурів, які виконали тест, практично до рівня інтактного контролю. На тлі сполуки КГМ-5 час пірнання серед усіх тварин і щурів, які успішно виконували тест, наближався до показників інтактних тварин.

Таблиця 3 - Вплив сполуки КГМ-5 та референс-зразків на результати тесту екстраполяційного вивільнення у щурів на 5-ту добу після моделювання закритої черепно-мозкової травми $\left(\mathrm{Me}\left(\mathrm{Q}_{25} ; \mathrm{Q}_{75}\right), \mathrm{n}=7\right)$

\begin{tabular}{|c|c|c|c|c|c|c|c|}
\hline \multirow{2}{*}{\multicolumn{2}{|c|}{ Показник }} & \multicolumn{5}{|c|}{ Група тварин } & \multirow{2}{*}{$\begin{array}{c}\text { Значення } \\
\text { критерію } \\
\text { Крускала - } \\
\text { Уолліса }\end{array}$} \\
\hline & & $\begin{array}{l}\text { інтактний } \\
\text { контроль }\end{array}$ & $\begin{array}{c}\text { контрольна } \\
\text { патологія } \\
\text { (ЗЧМТ) }\end{array}$ & $\begin{array}{c}\text { 3ЧМТ+КГМ-5, } \\
30 \mathrm{мг/кг}\end{array}$ & $\begin{array}{c}\text { ЗЧМТ+ГПК, } \\
150 \mathrm{мг/кг}\end{array}$ & $\begin{array}{c}\text { зЧМТ+ } \\
\text { пірацетам, } \\
300 \text { мг/кг }\end{array}$ & \\
\hline \multicolumn{2}{|c|}{$\begin{array}{l}\text { Кількість тварин, які } \\
\text { виконали тест/ } \\
\text { загальна кількість }\end{array}$} & $6 / 7$ & $6 / 7$ & $6 / 7$ & $6 / 7$ & $7 / 7$ & - \\
\hline \multirow{2}{*}{$\begin{array}{l}\text { Час } \\
\text { пірнання, } \\
\text { с }\end{array}$} & $\begin{array}{l}\text { серед усіх } \\
\text { тварин }\end{array}$ & $\begin{array}{c}17 \\
(12 ; 166)\end{array}$ & $\begin{array}{c}79 \\
(60 ; 170)\end{array}$ & $\begin{array}{c}19 \\
(15 ; 46)^{\star}\end{array}$ & $\begin{array}{c}19 \\
(3 ; 35)^{\star}\end{array}$ & $\begin{array}{c}14 \\
(9 ; 48)^{\star}\end{array}$ & 0,1218 \\
\hline & $\begin{array}{l}\text { серед щурів, } \\
\text { які виконали } \\
\text { тест }\end{array}$ & $\begin{array}{c}17 \\
(12 ; 110)\end{array}$ & $\begin{array}{c}77 \\
(60 ; 144)\end{array}$ & $\begin{array}{c}19 \\
(15 ; 28)^{\star}\end{array}$ & $\begin{array}{c}19 \\
(3 ; 31)^{*}\end{array}$ & $\begin{array}{c}14 \\
(9 ; 48)^{\star}\end{array}$ & 0,0216 \\
\hline
\end{tabular}

Примітки:

1. Використано критерій Манна - Уїтні (час пірнання) та кутове перетворення Фішера (кількість тварин, які виконали тест).

2. * рівень статистичної значущості відмінностей при порівнянні з групою контрольної патології $(p<0,05)$.

$\mathrm{n}$ - кількість тварин у групі.

Отже, сполука КГМ-5 статистично значуще поліпшує когнітивні функції щурів у віддалені терміни ЗЧМТ (на 5-ту добу): зменшує час виконання завдання в тесті екстраполяційного вивільнення як у загальній групі тварин, так і серед щурів, які здатні виконувати тест.

Важливо зазначити, що, за даними літератури, суттєві порушення когнітивних фрункцій у тесті екстраполяційного вивільнення, як і зниження локомоторної активності в тесті “відкрите поле", зареєстровано у щурів із ЗЧМТ у більш ранні терміни [16]. У подальшому, ймовірно, розвиваються компенсаторні зміни, внаслідок яких у цьому експерименті не спостерігали по- рушень когнітивних функцій ані у тварин групи контрольної патології, ані в щурів на тлі використання засобів. Важливо, що сполука КГМ-5 не перешкоджала даним змінам.

ВИСНОВОК. На моделі ЗЧМТ у щурів встановлено церебропротекторну активність нового похідного 4-амінобутанової кислоти - сполуки КГМ-5 за здатністю зменшувати вираження неврологічного дефріциту впродовж перших двох діб патології, запобігати зниженню локомоторної активності тварин без подальших зсувів орієнтовно-дослідницької активності та покращувати когнітивні фрункції.

\section{СПИСОК ЛІТЕРАТУРИ}

1. Ромнова Г. А. Моделирование черепно-мозговой травмы / Г. А. Ромнова, Ф. М. Шакова, А. Л. Парфенов // Патол. и эксперим. терапия. - 2015. - 59, № 2. - C. 112-115.

2. Loane D. J. Role of microglia in neurotrauma / D. J. Loane // Neurotherapeutics. - 2010. - 7, No. 4. P. 366-377.
3. Menon D. K. Traumatic brain injury / D. K. Menon, J. E. Risdall // Philosophical Transactions of the Royal Society B. Biological Sciences. - 2011. -366, No. 1562.P. 241-250.

4. Ousman S. S. Immune surveillance in the central nervous system / S. S. Ousman, P. Kubes // Nat. Neurosci. - 2012. - 15, No.8. - P. 1096-1101. 
5. Коррекция нарушений нейроиммунных взаимодействий при экспериментальной черепно-мозговой травме препаратом рекомбинантного интерлейкина-2 / С. Н. Шанин, Е. Е. Фомичева, Т. А. Филатенкова, Н. Б. Серебряная // Мед. иммунология. -2018. 20, № 2. - C. 171-178.

6. Ковальчук В. В. Когнитивная диссрункция. Современный взгляд на этиопатогенез, диагностику и терапию / В. В. Ковальчук // Эфрфективная фрармакотерапия. - 2020. - 16, № 31. - С. 40-52.

7. Пат. України на корисну модель № 120512, МПК (206), А 61K 31/197. Застосування похідних 4-амінобутанової кислоти як антиамнестичних засобів / Міщенко О. Я., Голік М. Ю., Гриценко І. С. та ін. ; заявник і патентовласник НФаУ. - № u201703627 ; заявл. 13.04.17; опубл. 10.11.17, Бюл. № 21.

8. Ельский В. Н. Моделирование черепно-мозговой травмы / . Н. Ельский, С. В. Зяблицев. - Донецк : Новый мир, 2008. - 140 с.

9. Востриков В. В. Место пирацетама в современной практической медицине / В. В. Востриков // Обзоры по клинической фрармакологии и лекарственной терапии. - 2017. - 15, № 1. - С. 14-25.

10. Уланова И. П. К вопросу об учете поверхности тела экспериментальных животных при токсикологическом исследовании / И. П. Уланова, К. К. Сидоров, А. И. Халепо // Токсикология новых промышленных химических веществ. - Л. : Медицина, 1968. Вып. 10. - С. 18-25.

11. Про затвердження Порядку проведення доклінічного вивчення лікарських засобів : наказ МОЗ
України від 14.12.2009 р. № 944 [Електронний ресурс]. - Режим доступу : https://zakon.rada.gov.ua/laws/ show/z0053-10\#Text.

12. Корекція неврологічних та когнітивних розладів на моделі церебральної ішемії з використанням оригінальних нейроактивних олігопептидів / Р. Д. Дейко, С. Ю. Штриголь, А. А. Колобов, О. Я. Міщенко // Фармакологія та лікарська токсикологія. - 2015. № 1. - C. 24-29.

13. Петри А. Наглядная медицинская статистика : учеб. пособ. / А. Петри, К. Сабин ; пер. с англ. под ред. В. П. Леонова. - 3-е изд., перераб. и дополн. - М. : гЭОТАР-Медиа, 2015. - 216 с.

14. Пирацетам в свете современных исследований (анализ зарубежных исследований) / А. С. Аведисова, Р. В. Ахапкин, В. И. Ахапкина, Н. Н. Вериго // Психиатрия и психофрармакотерапия. - 2000. - 2, № 6. - С. 178-84.

15. Нейротропные, противовоспалительные и противоопухолевые свойства молекулы гопантеновой кислоты по данным хемоинформационного анализа / О. А. Громова, И. Ю. Торшин, О. А. Лиманова [и др.] // Журн. неврологии и психиатрии. -2015. -5, вып. 2. С. 61-71.

16. Цывунин В. В. Нейропротекторные свойства сухих экстрактов дымянки Шлейхера и базилика камфорного / В. В. Цывунин, С. Ю. Штрыголь, Ю. С. Прокопенко // Обзоры по клинической фармакологии и лекарственной терапии. -2013. - 11, № 3. С. $66-71$.

\section{REFERENCES}

1. Romnova, G.A. (2015). Modelirovanie cherepnomozgovoy travmy [Simulation of traumatic brain injury]. Patologicheskaya i eksperimentalnaya terapiya - Pathological and Experimental Therapy, 59, 112-115 [in Russian].

2. Loane, D.J. (2010). Role of microglia in neurotrauma. Neurotherapeutics, 7 (4), 366-377.

3. Menon, D.K., \& Risdall, J.E. (2011). Traumatic brain injury. Philosophical Transactions of the Royal Society B. Biological Sciences, 366 (1562), 241-250.

4. Ousman, S.S., \& Kubes, P (2012). Immune surveillance in the central nervous system. Nat. Neurosci., 15 (8), 1096-1101.

5. Schanin, S.N., Vomitscheva, E.E., Vilatenkova, T.A., \& Cerebryanaya, N.B. (2018). Korrektsiya naruscheniy neyroimmunnykh vzaimodeystviy pri eksperimentalnoy cherepno-mozgovoy travme preparatom rekombinantnogo interleykina-2 [Correction of impaired neuroimmune interactions in experimental traumatic brain injury with the preparation of recombinant interleukin-2]. Meditsinskaya immunologiya - Medical Immunology, 20 (2), 171-178 [in Russian].

6. Kovalchuk, V.V. (2020). Kognitivnaya disfunktsiya. Sovremennyy vzglyad na etiopatogenez, diagnostiku i terapiyu [Cognitive dysfunction. Modern view of etiopathogenesis, diagnosis and therapy]. Effektivnaya farmakoterapiya - Effective Pharmacotherapy, 16 (31), 40-52. DOI 10.33978/2307-3586-2020-16-31-40-52 [in Russian].

7. Patent Ukrainy na korysnu model №120512; MPK (206), A 61K 31/197. Zastosuvannia pokhidnykh 4aminobutanovoi kysloty yak antyamnestychnykh zasobiv. O. Ya. Mishchenko, M. Yu. Holik, I. S. Hrytsenko ta in.; zaiavnyk i patentovlasnyk NFaU. № u201703627; zaiavl. 13.04.2017; opub. 10.11.2017. [in Ukrainian].

8. Elckiy, W.N., \& Zyablitsev, S.V. (2008). Modelirovanie cherepno-mozgovoy travmy [Cranio-cerebral trauma simulation]. Donetsk: Izd-vo "Novyy mir" [in Russian].

9. Vostrikov, V.V. (2017). Mesto piratsetama v sovremennoy prakticheskoy meditsine [The place of piracetam in modern practical medicine]. Obzory po klinicheskoy farmakologii i lekarstvennoy terapii - Reviews on Clinical Pharmacology and Drug Therapy, 15/1, 14-25 [in Russian].

10. Ulanova, I.P., Sidorov, K.K., \& Halepo, A.I.K. (1968). Voprosy ob uchete poverkhnosti tela eksperimentalnykh zhivotnykh pri toksikologicheskom issledovanii [On the issue of taking into account the body surface 
of experimental animals in toxicological research]. Toksikologiya novykh promyshlennykh himicheskikh veschestv. Leningrad: Meditsina [in Russian].

11. Nakaz MOZ Ukrainy № 944 "Pro zatverdzhennia Poriadku provedennia doklinichnoho vyvchennia likarskykh zasobiv" vid 14.12.2009 roku [On approval of the Procedure for conducting preclinical study of drugs: order of the Ministry of Health of Ukraine dated December 14, 2009 No. 944]. Retrieved from: https://zakon.rada. gov.ua/laws/show/z0053-10\#Text [in Ukrainian].

12. Deiko, R.D., Shtrygol, S.Yu., Kolobov, A.A., \& Mishchenko, O.Ya. (2015). Korektsiia nevrolohichnykh ta kohnityvnykh rozladiv na modeli tserebralnoi ishemii z vykorystanniam oryhinalnykh neiroaaktyvnykh olihopeptydiv [The correction of neurological and cognitive disorders on the model of cerebral ischemia using original neuroactive oligopeptides]. Farmakolohiia ta likarska toksykolohiia - Pharmacology and Drug Toxicology, 1, 24-29.

13. Petri, A., \& Sabin, K. (2015). Naglyadnaya meditsinskaya statistika: ucheb. posobie [Visual medical statistics: textbook]. Leonov, V.P. (Ed.). Moscow: GEOTAR-Media [in Russian].
14. Zyvunin, V.V., Schtrygol, Yu., Prokopenko, Yu.S. (2013). Neyroprotektornye svoystva sukhikh ekstraktov dimyanki Shleykhera i bazilika kamvornogo [Neuroprotective properties of dry extracts of Schleicher's smoke and basil camphor]. Obzory po klinicheckoy farmakologii i lekarstvennoy terapii-Reviews on Clinical Pharmacology and Drug Therapy, 11 (3), 66-71 [in Russian].

15. Awedicowa, A.C., Achapkin, R.W., Achapkina, W.I., \&Werigo, N.N. (2000). Piratsetam v svete sovremennykh issledovaniy (analiz zarubezhnykh issledovaniy) [Piracetam in the light of modern research (analysis of foreign research)]. Psikhiatriya i psikhofarmakoterapiya - Psychiatry and Psychopharmacotherapy, 2 (6), 178-184 [in Russian].

16. Gromova, O.A., Torschin, I.Yu., \& Limanova, O.A. (2015). Neyrotropnye, protivovospalitelnye i protivoopucholevye svoystva molekuly gopantenovoy kisloty po dannym khemoinformatsionnogo analiza [Neurotropic, anti-inflammatory and antitumor properties of the hopantenic acid molecule according to the data of chemoinformation analysis]. Zhurnal nevrologii i psikhiatrii Journal of Neurology and Psychiatry, 5 (2), 61-71 [in Russian].

\section{ЦЕРЕБРОПРОТЕКТОРНАЯ АКТИВНОСТЬ НОВОГО ПРОИЗВОДНОГО 4-АМИНОБУТАНОВОЙ КИСЛОТЫ В УСЛОВИЯХ ЭКСПЕРИМЕНТАЛЬНОЙ ЗАКРЫТОЙ ЧЕРЕПНО-МОЗГОВОЙ ТРАВМЫ}

\section{Резюме}

Вступление. Для лечения когнитивных расстройств в комплексной терапии черепно-мозговой травмы широко используют церебропротекторы и ноотропы.

Цель исследования - изучить церебропротекторную активность соединения КГМ-5, что является новым производным 4-аминобутановой кислоты.

Методы исследования. Закрытую черепно-мозговую травму (ЗЧМТ) воспроизводили у крыс массой 200-220 г под легким эфрирным наркозом с помощью груза массой 0,1 к2, свободно падающего по вертикальному каналу с энергией удара 0,589 Дж на голову животного. Всего было использовано 35 белых нелинейных крыс-самцов, которых разделили на группы: 1-я - интактный контроль; 2-я - животные со смоделированной зЧМТ; 3-я - животные со смоделированной зЧМТ, которым внутрижелудочно вводили соединение КГМ-5 в дозе 30 мг/ке; 4-я и 5-я - животные, которых лечили, сооответственно, препаратами сравнения гопантеновой кислотой (150 мг/кг внутрижелудочно) и пирацетамом (300 мг/кг внутрижелудочно) в течение 3 суток до и 5 суток после моделирования ЗчМТ. На 1-е, 2-е и 3-е сутки после воспроизведения ЗЧМТ определяли степень неврологического дефицита (в баллах) по шкале McGraw, на 4-e фрункциональное состояние ЦНС животных в тесте "откритое поле", на 5-е - когнитивные функции в тесте экстраполяционного высвобождения.

Результаты и обсуждение. На фроне действия исследуемых средств установлено уменьшение неврологического дефицита по сравнению с группой контрольной патологии на 1-е и 2-е сутки, однако достоверный характер эти различия имели только на 1-е сутки. В тесте "откритое поле" двигательная и исследовательская активность и общая сумма всех видов активности на фроне действия всех средств была достоверно выше, чем в группе контрольной патологии. В тесте экстраполяционного высвобождения как в общей группе животных, так и среди крыс, которые способны выполнять тест, соединение КГМ-5 статистически значимо улучшало когнитивные фрункции животных: уменьшало время решения задачи.

Вывод. На модели закрытой черепно-мозговой травмы у крыс установлено церебропротекторную активность нового производного 4-аминобутановой кислоты - соединения КГМ-5 по способности умень- 
шать выраженность неврологического дефицита в течение первых двух суток патологии, предотвращать снижение локомоторной активности животных и улучшать когнитивные функции.

КЛЮЧЕВЫЕ СЛОВА: новое производное 4-аминобутановой кислоты КГМ-5; моде ль закрытой черепно-мозговой травмы; неврологический дефицит, состояние цНС; когнитивные функции.

N. Yu. Palagina

NATIONAL UNIVERSITY OF PHARMACY, KHARKIV

\section{CEREBROPROTECTIVE ACTIVITY OF A NEW DERIVATIVE OF 4-AMINOBUTANIC ACID IN EXPERIMENTAL CONDITIONS OF CLOSED CRANIOCEREBRAL INJURY}

\section{Summary}

Introduction. Cerebroprotectors and nootropics are widely used for cognitive disorders treatment in the complex therapy of craniocerebral injury (CCl).

The aim of the study - to investigate the cerebroprotective activity of the compound KGM-5 - a new derivative of 4-aminobutanoic acid.

Research Methods. Closed CCI was reproduced in rats weighing 200-220 g under light ether anesthesia by free $0.1 \mathrm{~kg}$ weight falling along a vertical channel with an impact energy of $0.589 \mathrm{~J}$ per animal's head. 35 white nonlinear male rats were used. Group 1 - intact control, group 2 - animals with $\mathrm{CCCl}(C P)$, groups 3, 4 and 5 of animals with $\mathrm{CCCl}$, which were treated, respectively, with compound KGM-5 (30 mg/kg intragastrically (i/g), with comparison drugs hopantenic acid (150 mg/kg i/g) and piracetam (300 mg/kg i/g) for 3 days before and 5 days after CCCl. On days 1, 2, 3 after CCCl, the degree of neurological deficit (in points) according to the McGraw scale, on day 4 - the functional state of the CNS of animals in the open field test, on day 5-cognitive functions in the extrapolation release test were determined.

Results and Discussion. Under the agents influence a neurological deficit decrease compared with CP group on the first and second days was established. In the "open field" test, motor and exploratory activity and the total amount of activities under the agents action were significantly higher. In the extrapolation release test KGM-5 improve rats' cognitive functions.

Conclusions. On the CCCI model in rats cerebroprotective activity of compound KGM-5 was established by its ability to reduce the severity of neurological deficit during the first two days of pathology, prevent the locomotor activity decrease and improve cognitive functions of animals.

KEY WORDS: new derivative of 4-aminobutanoic acid KGM-5; model of closed craniocerebral injury; neurological deficit; central nervous system state; cognitive functions.

Отримано 04.03.21

Адреса для листування: Н. Ю. Палагіна, Національний фрармацевтичний університет, Інститут підвищення кваліфрікації спеціалістів фармації, майдан Захисників України, 17, Харків, 61001, Україна, e-mail: palaginanatasha@ukr.net. 